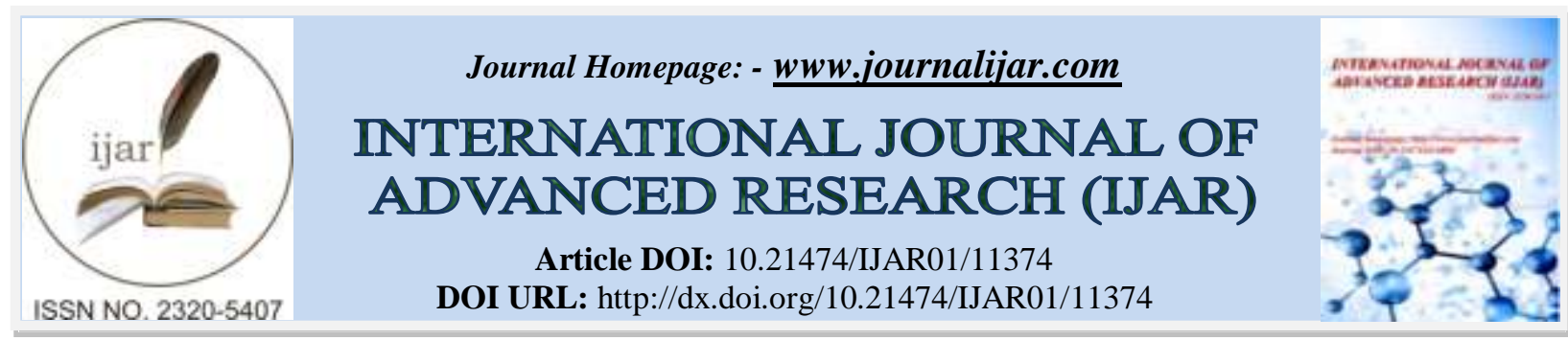

RESEARCH ARTICLE

\title{
THE MEDIATING EFFECT OF JOB SATISFACTION ON THE RELATIONSHIP BETWEEN ORGANIZATIONAL CULTURE AND LECTURES' INNOVATIVE BEHAVIOUR IN INDONESIAN PRIVATE HIGHER EDUCATION
}

E. Michael Bayudhirgantara

Lecture, Post Graduate Program, Department of Management Science, Faculty of Economic and Business, Mercu Buana University, Jakarta, Indonesia.

\section{Manuscript Info}

\section{Manuscript History}

Received: 20 May 2020

Final Accepted: 24 June 2020

Published: July 2020

Key words:-

Organizational Culture, Job Satisfaction,

Innovative Behaviour

\begin{abstract}
The objective of this research is to study the effect of organizational culture and jo b satisfaction on lecture's innovative behaviour at in Indonesian Private Higher Education. Quantitative approach used in this research with survey method. The samples of this research were 210 lectures selected randomly. The data were obtained by distributing a questionnaire and analyzed by using path analysis. The results of the research can be concluded that organizational culture had a positive direct effect on lecture's job satisfaction and innovative behaviour. Job satisfaction also had a positive direct effect on lecture's innovative behaviour. Other finding showed indirect effect of organizational culture on lecture's innovative behaviour mediated by job satisfaction. Therefore to improve lecture's innovative behaviour, then organizational culture and job satisfaction should be improved.
\end{abstract}

Copy Right, IVAR, 2020,. All rights reserved.

\section{Introduction:-}

The role of higher education is crucial to develop excellent human resources and high competitiveness. Higher education with strong competitiveness at the global level will strengthen the positive image of the nation and increasing the country's success in improving the welfare of its people. Therefore, higher education is demanded to become an institution not only as a producer of knowledge, but also as an independent human forming institution and able to solve various individual and national problems through ways of thinking that are more creative, innovative, proactive and anticipative. In conditions with intense competition, every higher education must be able to build quality human resources. Human resources is the most important factor to carry out organizational functions optimally. In the higher education, the lecturer has a strategic role and an important pillar for achieving success, because lecturers are at the front line in transferring knowledge to students and as the main subject in the higher education environment. Globally the facts show that universities in Indonesia have not shown satisfactory achievements. Based on the QS World University Ranking, leading universities such as the University of Indonesia ranks 305, Gadjah Mada University ranks 320, and Bandung Institute of Technology ranks 331 (QS World University Ranking, 2020).

One important factor needed by universities to strengthen competitiveness is lecturer innovation. Innovation at the individual level or lecturers' innovative behaviour is needed so that universities become more innovative and can produce useful findings. Innovative behaviour is believed to be a driver of competitiveness in various types and scales of companies or organizations (Cropley \& Cropley, 2009; Nemeržitski, Loogma, Heinla, \& Eisenschmidt, 
2013), including in the higher education (Bjornali \& Støren, 2012; Gulden, Saltanat, Raigul, Dauren, \& Assel, 2020; Hasanefendic, Birkholz, Horta, \& van der Sijde, 2017). Innovation in the higher education is needed because of changing market conditions that require new skills and knowledge (Lambriex-Schmitz, Van der Klink, Beausaert, Bijker, \& Segers, 2020). Lecturers or teachers are key factors that determine innovation in higher education (George \& Sabapathy, 2011; Koeslag-Kreunen, Van der Klink, Van den Bossche, \& Gijselaers, 2018; Lambriex-Schmitz et al., 2020). Innovation requires lecturers to develop new behaviour and leave routines (Verloop, Driel, \& Meijer, 2001). Therefore, the progress and quality of higher education highly depends on the ability of lecturers to innovate.

Research on innovative behaviour of lecturers in higher education relatively limited so far, so it is important to expand research on lecturers innovative behaviour. This study aims to investigate the role of job satisfaction factors as a mediator the influence of organizational culture on lecturers innovative behaviour. This research is expected to contribute in developing efforts to improve the lecturers innovative behaviour in higher education.

\section{Literature Reviews and Hypotheses Development:}

In a competitive business environment, innovation is a key factor that every organization must have in order to be successful. Innovation means "the process of creating a commercial product from invention" (Ireland, Hoskisson, \& Hitt, 2011, p. 334). Hill and Hult (2016, p. 68) define innovation as "the development of new products, processes, organizations, management practices, and strategies". Thus innovation means an effort to renewal products, services, work processes, organizational management, business processes and others with to produce more and better benefits than before.

Innovation in organizations can be seen at the individual level, which is called innovative behaviour. Janssen (2004) explain innovative behaviour as intentional creation, introduction and application of new ideas that benefit to the organization. In another explanation Carmeli, Meitar, and Weisberg (2006) states that innovative behaviour is a gradual process whereby an individual recognizes a problem to derive new ideas and solutions, works to advance and build support, and produces a prototype that is applied or a model to be used and benefits the organization. In the context of an educator or lecturer, innovative behaviour reflects his ability to provide students with new models and tools for class activities that have not been known before, thus fostering student creativity and producing new learning processes (Nemeržitski et al., 2013).

According to Scott and Bruce (1994) individual innovation begins with generating an ideas, namely the production and use of new ideas in several domains. The next stage of the innovation process is the promotion of ideas towards potential incorporation. Once an individual generates an idea, the individual is engaged in social activities to finding friends, supporters, and sponsors or building a coalition of supporters who provide important power to realize ideas. The final task of the innovation process relates to the realization of ideas by producing a prototype or innovation model that can be felt and its peak is applied in the work role, group, or organization as a whole.

Kleysen and Street (2001) work from factor analysis produces five dimensions to measure innovative behaviour. First, opportunity exploration, includes paying attention to sources of opportunities, seeking opportunities for innovation, recognizing opportunities, and gathering information about opportunities. Second, generativity, related to behaviour directed to produce beneficial changes, such as generating ideas or solutions for opportunities, producing representations or categories of opportunities, and producing associations and combinations of ideas and information. Third, informative investigation, related to giving form and issuing ideas, solutions and opinions as shown by formulating ideas and solutions, demonstrating ideas and solutions, evaluating ideas and solutions. Fourth, championing, includes socio-political behaviour that involves innovation processes and it is important to realize potential solutions, ideas and innovations as demonstrated by mobilizing resources, persuading and influencing, encouraging and negotiating, challenging and taking risks. Fifth, application, shown by implementing, modifying, and getting used.

\section{Organizational culture and innovative behaviour:}

The popular concept of organizational culture explained by Schein (2010, p. 18), "a pattern of basic assumtionsinvented, discovered, or developed by a given group as it learns to cope with a problems of external adaptation and internal integration that has worked well enough to be considered perceive, think, and feel in relation to those problems". This definition provides an understanding that organizational culture is manifested in the form of assumptions and beliefs that become a common reference by members of the organization in solving various 
problems faced by the organization. Organizational culture means acting as an unwritten code of conduct, so that its implementation is based on awareness and commitment from members of the organization and also the leader.

Dawson (2010) describe organizational culture in two elements, namely as personality and capabilities. Culture as personality refers to the qualitative, subjective, and experience aspects of climate and organizational values, while culture as a capability mentions goals, more easily measured, often described as levers that can be drawn to shape the creation of distinctive capability values. Carnall and By (2014) states that organizational culture as attitudes, values, beliefs, norms, and habits that distinguish between one organization with another organization. From this view, it can be understood that organizational culture contains important components that are not visible, such as attitudes, values, beliefs, norms and habits. Although not visible, these aspects affect members of the organization in acting and behaving. Various aspects are also a differentiator between one organization with another organization.

A strong organizational culture is needed because according to McShane dan Glinow (2015) organizational culture has three important functions. First, as a control system, the organizational culture is deeply institutionalized in the form of social control that affects employee decision making and behaviour. Second, social glue, which binds people together and makes feelings a part of organizational experience. Third, sense-making, which helps the process of creating understanding, helping to understand what must be continued, why something happens in the company, to understand what is expected, and to interact with other employees.

Organizational culture also has an important role in influencing innovation within the organization. This is as stated by Sims (2006b, p. 5), "strategic human resource management (SHRM) can be defined as the linking of human resources with strategic goals and objectives in order to improve business performance and developed organizational culture that foster innovation and flexibility". This was also shown by Herzog (2011, p. 59) "scholars and practitioners argue that organizational culture has a strong impact on innovation and innovation success". Thus it is clear that organizational culture theoretically influences innovation. Previous research also proves that organizational culture has a significant influence on innovative behaviour (Eskiler, Ekici, Soyer, \& Sari, 2016; LealRodríguez, Eldridge, Ariza-Montes, \& Morales-Fernández, 2019; Naranjo-Valencia, Jiménez-Jiménez, \& SanzValle, 2011; Stoffers, Neessen, \& Dorp, 2015). Thus the following hypothesis can be formulated:

H1:

Organizational culture has a positive direct effect on innovative behaviour

\section{Job satisfaction and innovative behaviour:}

Byars and Rue (2008, p. 238) define job satisfaction as "job satisfaction is an employee's general attitude toward the job." Furthermore Byars and Rue explain that job satisfaction synonymous with organizational morals, that is the feelings of employees become accepted and involved in the group of employees through shared goals, trust in shared goals, and a desire to increase towards goals. Another definition stated by Spector (1997, p. 2) "job satisfaction is the degree to which people like their jobs". This means that job satisfaction is the degree to which people like their work. Kinicki and Kreitner (2008, p. 162) also explain that job satisfaction as "an affective or emotional response to one's job". This definition shows that job satisfaction is a feeling or emotional response to one's work. Job satisfaction is not a generally accepted concept, but one can feel relative satisfaction with one aspect and not be satisfied with other aspects.

Theoretically, the effect of job satisfaction on innovative behaviour can be seen from the statement by Wicker (2011, p. 3) "to the worker, job satisfaction brings a pleasurable emotional state that often leads to a positive work attitude and improved performance. A satisfied worker is more likely to be creative, flexible, innovative and loyal". From the statement it is clear that for employees, job satisfaction brings pleasant emotional conditions that often lead to positive work attitudes and improve performance. Satisfied workers are more creative, flexible, innovative and loyal. These conditions generally apply to every organization, including those in higher education. Therefore it can be assumed that job satisfaction has a direct positive effect on innovative behaviour. Previous research related to the effect of job satisfaction on innovative behaviour is carried out by Tien and Chao (2012) with the results show that job satisfaction has a positive effect on organizational innovation. Another researchs by Bsysted (2013), Chung and Kim (2017) and Niu (2014) also indicated the important role of job satisfaction in influencing innovative behaviour. Thus the following hypothesis can be formulated: 
H2:

Job satisfaction has a positive direct effect on innovative behaviour

\section{Organizational culture and job satisfaction:}

Job satisfaction arises when an employee perceives positively and feels happy with their work. The feeling of pleasure is driven by conformity with aspects of job satisfaction such as work, salary, promotion, coworkers, supervision, and working conditions (Colquitt, LePine, \& Wesson, 2017). In order to create aspects of work that are conducive and enjoyable is necessary to have a supportive organizational culture, values that promise the availability and implementation of aspects of work properly and adequately. The important role of organizational culture in influencing job satisfaction is revealed by Kandula (2006, p. 155) "culture is one of the significant determinants of job satisfaction. People prefer organizations known as the best employers where opportunities for job satisfaction are fertile. It has been conclusively proven that organizational culture plays the decisive role in creating conditions for job satisfaction”. From the statement above it seems clear that culture is a significant determinant of job satisfaction, because a positive and strong organizational culture enables employees to transform their potential into real performance by maximizing strengths and reducing weaknesses, and ultimately the organizational culture that is oriented to improving performance will create norms and habits that facilitate job satisfaction. Previous research also indicated that organizational culture as a determinant of job satisfaction (Bellou, 2010; Pawirosumarto, Sarjana, \& Gunawan, 2017; Zavyalova \& Kucherov, 2010). Thus the following hypothesis can be formulated:

\section{H3:}

Organizational culture has a positive direct effect on job satisfaction

\section{Organizational culture, job satisfaction and innovative behaviour:}

Based on the previous explanation, it is known that theoretically organizational culture plays a role in increasing job satisfaction (Herzog, 2011; Sims, 2006), and also proved from the results of previous studies that organizational culture as a predictor of job satisfaction (Eskiler et al., 2016; Leal-Rodríguez et al., 2019; Naranjo-Valencia et al., 2011; Stoffers et al., 2015). While for job satisfaction theoretically also contributes to increasing innovative behaviour (Wicker, 2011) and based on the previous studies job satisfaction affect on innovative behaviour (Bysted, 2013; Carmeli et al., 2006; Niu, 2014; Tien \& Chao, 2012). Such patterns of influence enable organizational culture to have an indirect influence on innovative behaviour or in other words job satisfaction as a mediator of the influence of organizational culture on innovative behaviour. A strong organizational culture will increase job satisfaction and ultimately increase innovative behaviour. Thus the following hypothesis can be formulated:

H4:

Job satisfaction as a mediator on the relationship between organizational culture and innovative behaviour

Based on the theoretical description and previous research which has been explained above, the research framework can be illustrated in Figure 1.

$\mathrm{H} 1$

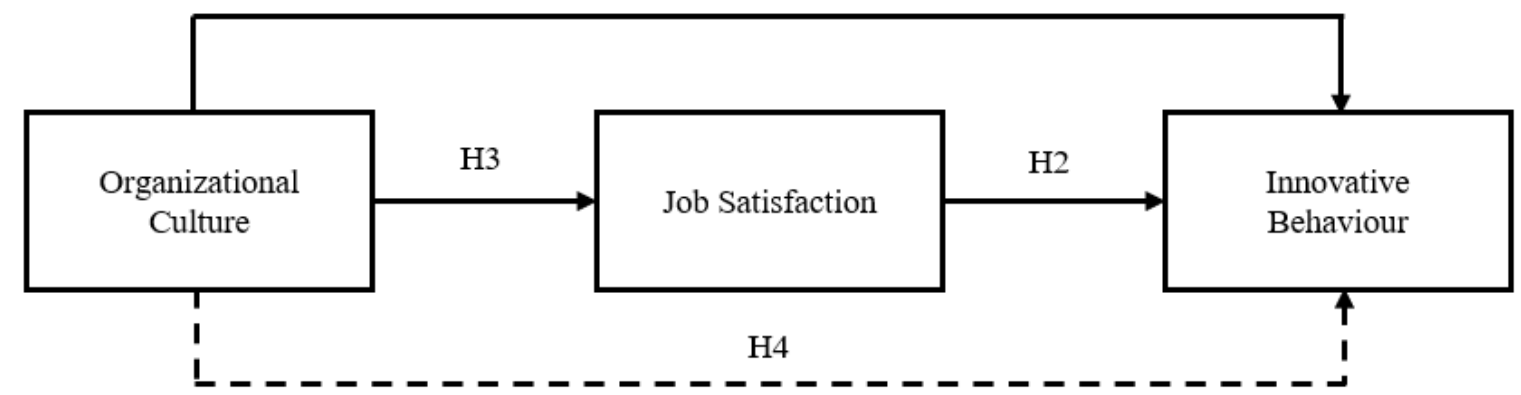

Fig 1:- Theoretical framework.

\section{Research Methods:-}

This study uses a quantitative approach through survey methods, namely research aimed at assessing large and small populations by selecting and reviewing selected samples from that population to find the relative incidence, 
distribution, and interrelation of variables (Kerlinger \& Lee, 2000). Specifically, surveys are used to study the attitudes, beliefs, values, demographics, behaviour, opinions, habits, desires, ideas and other types of information (McMillan \& Schumacher, 2006). In this study, the population is all private university lecturers in Coordination of Private Higher Education Region III Jakarta (Kopertis Region III Jakarta). Meanwhile, the target population as the sample frame are the lecturer who teaches undergraduate level in private university lecturers in Kopertis Region III Jakarta who already have a National Lecturer Registration Number (NIDN) with total 17829 lecturers. In accordance with the research method used (survey), then to determine the number of samples used the reference from table Bartlett, Kotrlik, \& Higins (2001) with error rate $(\alpha)$ 1\%, then for populations above 10,000 a minimum sample required is 209 . In this research, sample was rounded up to 210 lecturers taken by simple random sampling.

Data collection was carried out using questionnaire with a five-point Likert scale from Never (1) to Always (5). The innovative behaviour questionnaire was developed based on indicators: generating idea, looking for opportunities, seeking support, championing, and application (Kleysen and Street, 2001). The reliability test results obtained Alpha $0.930>0.7$ which means that innovative behaviour instruments are reliable and deserve to be used as a research instruments. The organizational culture questionnaire was developed based on indicators: academic spirit, research development, critical, academic freedom, professional service, collaboration, support, and academic ethics (Davies, Douglas, \& Douglas, 2007; Shen \& Tian, 2012) with Alpha $0.974>0.7$. While the job satisfaction questionnaire was developed based on indicators: job itself, payment, promotion, supervision, coworkers, and working conditions (Colquitt, LePine, \& Wesson, 2019) with Alpha $0.966>0.7$. Data analysis was performed using path analysis which was calculated with LISREL 8.8.

\section{Results and Discussion:-}

The first section presented from the results of this study is a description of the respondents demographics ( $\mathrm{n}=210$ ). This study involved a sample of 210 lecturers consisting of male $63.8 \%$ and female $36 . \%$. The age of respondents is mostly 41-50 years $(58.6 \%)$, followed by ages $31-40$ years $(34.3 \%)$, <30 years $(4.3 \%)$, and $>50$ years $(2.9 \%)$. Most of respondents have worked 11-15 years (45.2\%), and followed by 5-10 years $(38.6 \%)$, > 15 years $(9 \%)$, and $<5$ years $(7.1 \%)$. While for marital status majority of respondents have married $(91.0 \%)$ and who are still single $9 \%$.

The first section presented from the results of this study is a description of the respondents demographics. This study involved a sample of 210 lecturers consisting of male $63.8 \%$ and female $36 . \%$. The age of respondents is mostly 41 50 years $(58.6 \%)$, followed by ages $31-40$ years $(34.3 \%)$, < 30 years $(4.3 \%)$, and > 50 years $(2.9 \%)$. Most of respondents have worked 11-15 years $(45.2 \%)$, and followed by $5-10$ years $(38.6 \%)$, > 15 years $(9 \%)$, and < 5 years $(7.1 \%)$. While for marital status majority of respondents have married (91.0\%) and who are still single $9 \%$.

Table 1:- Demographic Description.

\begin{tabular}{|l|l|l|}
\hline Description & Frequency (F) & Percentage (\%) \\
\hline Gender & & \\
\hline Male & 134 & 63.8 \\
\hline Female & 76 & 36.2 \\
\hline Age & & \\
\hline$<30$ & 9 & 4.3 \\
\hline $31-40$ & 72 & 34.3 \\
\hline $41-50$ & 123 & 58.6 \\
\hline$>50$ & 6 & 2.9 \\
\hline & & \\
\hline Tenure & & \\
\hline$<5$ & 15 & 7.1 \\
\hline $5-10$ & 81 & 38.6 \\
\hline $11-15$ & 95 & 45.2 \\
\hline$>15$ & 19 & 9.0 \\
\hline Marital status & & \\
\hline Married & 191 & 91.0 \\
\hline Single & 19 & 9.0 \\
\hline
\end{tabular}


The next section included descriptive statistics for all varibles. Correlation coefficient among variables and descriptive statistics of each variables showed in Table 2. The correlation coefficients among variables range from 0.741 to 0.790 with the strongest correlation between organizational culture and job satisfaction $(r=0.790)$ and the lowest correlations between job satisfaction and innovative behaviour ( $\mathrm{r}=0.741)$, while for correlation between organizational culture and innovative behaviour 0.755 . The descriptive statistics for organizational culture variable scored from minimum 2.90 to 5.00 with mean score of 4.10 and standard deviation of 0.40 . Job satisfaction variable have score range from 3.10 to 5.00 with a mean score of 4.09, and standard deviation of 0.42 . Further for innovative behaviour variable have score range from 3.0 to 4.90 with mean score of 3.97 and standard deviation of 0.44 .

Table 2:- Descriptive statistics of the variables.

\begin{tabular}{|l|l|l|l|}
\hline Variables & 1 & 2 & 3 \\
\hline 1. Organizational Culture & 1.000 & & \\
\hline 2. Job Satisfaction & $0.790^{* *}$ & 1.000 & \\
\hline 3. Innovative Behaviour & $0.755^{* *}$ & $0.741^{* *}$ & 1.000 \\
\hline Minimum & 2.90 & 3.10 & 3.00 \\
\hline Maximum & 5.00 & 5.00 & 4.90 \\
\hline Mean & 4.10 & 4.09 & 3.97 \\
\hline Standard deviation & 0.40 & 0.42 & 0.44 \\
\hline
\end{tabular}

** p-value $<0,01$

After the descriptive statistics are presented for each variable, then continued to hypothesis testing. Hypothesis testing uses path analysis and is calculated using LISREL 8.8.

Table 3:- Beta and t-value for hypothesis testing.

\begin{tabular}{|l|l|l|l|l|}
\hline No. & Variables Effect & Beta & t-value & Decision \\
\hline 1. & OC $\rightarrow$ JS & $0.359^{* *}$ & 4.853 & Accepted H1 \\
\hline 2. & OC $\rightarrow$ IB & $0.483^{* *}$ & 6.525 & Accepted H2 \\
\hline 3. & JS $\rightarrow$ IB & $0.540^{* *}$ & 6.915 & Accepted H3 \\
\hline 4. & OC $\rightarrow$ JS $\rightarrow$ IB & $0.261^{* *}$ & 4.746 & Accepted H4 \\
\hline
\end{tabular}

** p-value $<0,01$

$\mathrm{OC}=$ Organizational Culture, $\mathrm{JS}=$ Job Satisfaction; $\mathrm{IB}=$ Innovative Behaviour

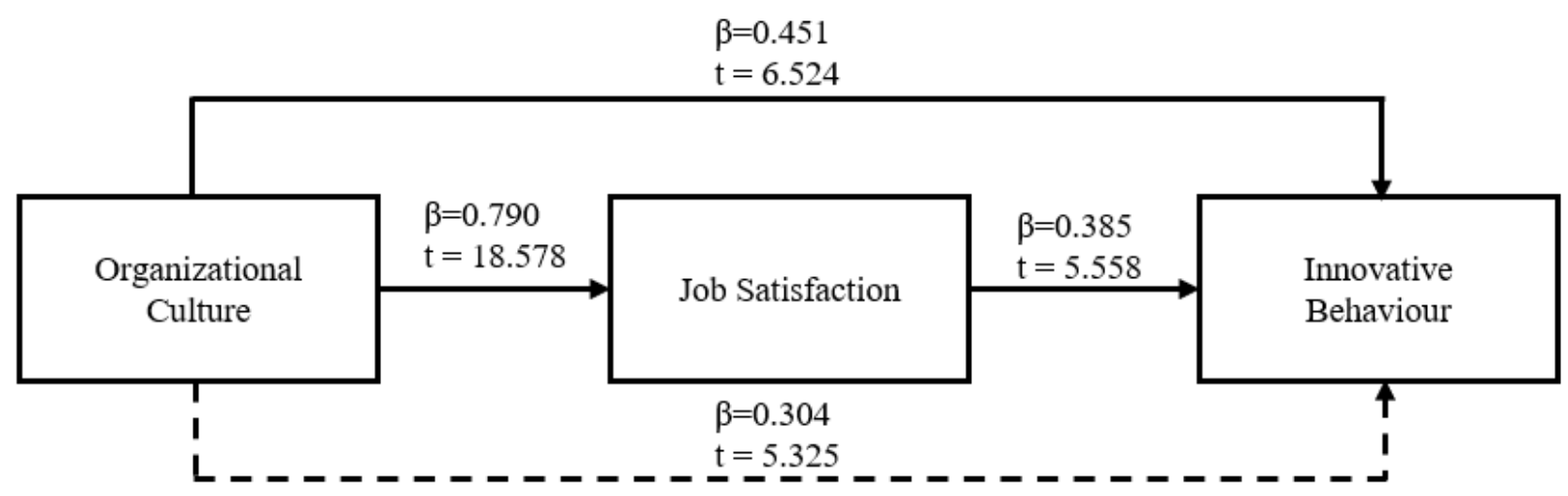

Fig 2:- Beta and t-value.

The result from path analysis shows the direct effect of organizational culture on innovative behaviour obtained path coefficient or beta value $(\beta) 0.451$ and t-value 6.524 , whereas the t-critical value at $95 \%$ confidence level $(\alpha=0.05)$ is 1.96. The results show t-value (6.524) > t- critical value (1.96), which means accepted H1, so organizational culture has a direct positive effect on innovative behaviour. Further for the direct effect of job satisfaction on innovative behaviour obtained beta value 0.385 with t-value $5.558>1.96$. Therefore accepted $\mathrm{H} 2$ and this means job satisfaction has a positive direct effect on innovative behaviour. Beta value for the direct effect of organizational culture on job satisfaction is 0.790 with t-value of $18.578>1.96$ which means accepted H3. This means that organizational culture has a positive direct effect on job satisfaction. While for mediating effect organizational culture on innovative behaviour through job satisfaction was obtained beta value 0.304 with t-value $5.325>1.96$ 
which means accepted H4. This means that job satisfaction mediated the effect of organizational culture on innovative behaviour.

The results of hypothesis testing prove that organizational culture has a positive and significant effect on innovative behaviour. The findings show that improving organizational culture will positively have an impact on increasing innovative behaviour. In the context of higher education, the importance of organizational culture in influencing innovative behaviour can be understood. Organizational culture shows the values that are believed together in an organization which is the basis for behaving and solving problems. The values that become beliefs cover many aspects, including the belief to be individuals who continue to progress and excel and uphold hard work. If a company has such values, it will encourage members of the organization to always think and make the breakthroughs needed to succeed in their duties. In other words, organizations that have values uphold performance can encourage members of their organizations to act innovatively in order to realize their best achievements.

The relationship between organizational culture and innovation is explained by Sims (2006) that the development of organizational culture in the context of strategic human resource management is aimed at strengthening innovation and flexibility. This is also supported by the opinion of Herzog (2011) that organizational culture has a strong impact on innovation success. Previous research by Eskiler, Ekici, Soyer, and Sari (2016) also showed organizational culture as an antecedent of innovative behaviour. Other studies also indicated the results that organizational culture influences innovative behaviour (Leal-Rodríguez, Eldridge, Ariza-Montes, \& MoralesFernández, 2019; Naranjo-Valencia, Jiménez-Jiménez, \& Sanz-Valle, 2011; Stoffers, Neessen, \& Dorp, 2015). Thus, the results of this study support and strengthen previous theories that explain the importance of organizational culture in promoting innovative behaviour.

Job satisfaction based on the results of hypothesis testing is also proven to have a positive and significant effect on innovative behaviour. These findings explain that empirically increasing job satisfaction will have an impact on increasing innovative behaviour. This result can be understood because every person who works expects satisfaction at work, then job satisfaction if fulfilled will have an impact on the positive behaviour of an employee. One of the positive behaviours that can be generated is innovative behaviour. Theoretically, the effect of job satisfaction on innovative behaviour explained Wicker (2011) that job satisfaction brings pleasant emotional conditions that often lead to positive work attitudes and satisfied workers are more creative, flexible, innovative and loyal. Previous research also proved the influence of job satisfaction on innovative behaviour (Bsysted, 2013; Chung \& Kim, 2017; Niu, 2014; Tien \& Chao, 2012). With these results, the study support theories and previous research that show the important role of job satisfaction in building innovative behaviour.

Based on the results of hypothesis testing, in addition to influencing innovative behaviour, organizational culture also has a positive and significant effect on job satisfaction. The findings show that improving organizational culture will have an impact on increasing job satisfaction. The important role of organizational culture on job satisfaction can occur because the existence of quality organizational culture influences individual behaviour and attitudes (Tiwari, 2009), including in the form of job satisfaction. Kandula (2006) asserts that culture is one of the determinants of job satisfaction. Previous research also proves that organizational culture influences job satisfaction (Bellou, 2010; Pawirosumarto et al., 2017; Zavyalova \& Kucherov, 2010). Thus the results of this study support the theories and previous research that shows the important role of organizational culture in increasing job satisfaction.

Job satisfaction in this study also proved to play a role as a mediator variable in the influence of organizational culture on innovative behaviour. This finding shows that organizational culture that supports and is well implemented will increase job satisfaction and subsequently have the effect of increasing innovative behaviour. These results are inseparable from the results of previous hypothesis testing which proves that organizational culture directly influences job satisfaction and job satisfaction directly influences innovative behaviour. Such direction of influence enables the indirect influence of organizational culture on innovative behaviour through job satisfaction.

The implication from this study that each higher education must place organizational culture and job satisfaction as a strategic factor to encourage innovative behaviour of lecturers. Therefore, the organizational culture in each higher education must be strengthened by increasing academic spirit, providing support to lecturers, developing academic freedom, strengthening critical culture, and developing stronger cooperation in the higher education. Each higher education management will also evaluate the compensation system, improve the supervision system, improve work conditions and harmonious communication between campus residents as an effort to increase job satisfaction. 


\section{Conclusion and Recommendation:-}

Innovative behaviour is a key success factor in strengthening the competitiveness of higher education. This study shows the conclusion that innovative behaviour is significantly influenced by organizational culture and job satisfaction. A strong organizational culture and high job satisfaction will have an impact on increasing the lecturers innovative behaviour. Job satisfaction is also known as a mediator variable of the influence of organizational culture on innovative lecturers behaviour. Based on these conclusions, the organizational culture needs to be improved by strengthening academic spirit, providing support to lecturers, and developing collaboration. Academic spirit can be developed by instilling an awareness about the importance of values in education, such as the spirit of selfdevelopment, the willingness to continue learning, and the passion to show achievement. Providing support to lecturers can be carry out by providing facilities such as books, providing scholarships for outstanding lecturers, and providing facilities and infrastructure to support lecturers in carrying out their duties. Development of cooperation is carried out by intensifying cooperation with other campuses for the development of education that involves lecturers. Job satisfaction is also enhanced by improving the compensation system, supervision, and seeking harmonious relationships. The compensation system must be ensured to fulfill internal and external justice. Supervision needs to be done with an educative approach and not prioritized supervision to find faults and only formalities. Meanwhile, to build relationships and communication on campus, it is necessary to have routine activities among lecturers to strengthen the sense of kinship and cooperation.

\section{References:-}

1. Bartlett, J. E., Kotrlik, J. W., \& Higins, C. C. (2001). Organizational research: determining appropriate sample size in survey research. Information Technology, Learning, and Performance Journal, 19(1), 43-50.

2. Bellou, V. (2010). Organizational culture as a predictor of job satisfaction: The role of gender and age. Career Development International, 15(1), 4-19. https://doi.org/10.1108/13620431011020862

3. Bjornali, E. S., \& Støren, L. A. (2012). Examining competence factors that encourage innovative behaviour by European higher education graduate professionals. Journal of Small Business and Enterprise Development, 19(3), 402-423. https://doi.org/http://dx.doi.org/10.1108/14626001211250135

4. Byars, L. L., \& Rue, L. W. (2008). Human Resource Management. New York: McGraw-Hill Company, Inc.

5. Bysted, R. (2013). Innovative employee behaviour: The moderating effects of mental involvement and job satisfaction on contextual variables. European Journal of Innovation Management, 16(3), 268-284. https://doi.org/10.1108/EJIM-09-2011-0069

6. Carmeli, A., Meitar, R., \& Weisberg, J. (2006). Self-leadership skills and innovative behaviour at work. International Journal of Manpower, 27(1), 75-90. https://doi.org/10.1108/01437720610652853

7. Carnall, C., \& By, R. T. (2014). Managing Change in Organizations. Harlow: Pearson Education, Inc.

8. Chung, Y. W., \& Kim, T. (2017). Impact of using social network services on workplace ostracism, job satisfaction, and innovative behaviour. Behaviour and Information Technology, 36(12), 1235-1243. https://doi.org/10.1080/0144929X.2017.1369568

9. Colquitt, J. A., LePine, J. A., \& Wesson, M. J. (2017). Organizational Behaviour: Improving Performance and Commitment in the Workplace (5th ed.). New York: McGraw-Hill Education.

10. Colquitt, J. A., LePine, J. A., \& Wesson, M. J. (2019). Organizational Behaviour: Improving Performance and Commitment in the Workplace (6th ed.). https://doi.org/10.1002/pdh.22

11. Cropley, A. J., \& Cropley, D. H. (2009). Fostering creativity: A diagnostic approach forhigher education and organizations. Cresskill: Hampton Press.

12. Davies, J., Douglas, A., \& Douglas, J. (2007). he Effect of Academic Culture on The Implementation of the EFQM Excellence Model in UK universities. Quality Assurance in Education, 15(4), 382-401.

13. Dawson, C. S. (2010). Leading Culture Change. California: Stanford University Press.

14. Eskiler, E., Ekici, S., Soyer, F., \& Sari, I. (2016). The relationship between organizational culture and innovative work behaviour for sports services in Tourism enterprises. Physical Culture and Sport, Studies and Research, 69(1), 53-64. https://doi.org/10.1515/pcssr-2016-0007

15. George, L., \& Sabapathy, T. (2011). Work Motivation of Teachers: Relationship with Organizational Commitment. Canadian Social Science, 7(1), 90-99.

16. Gulden, M., Saltanat, K., Raigul, D., Dauren, T., \& Assel, A. (2020). Quality management of higher education: Innovation approach from perspectives of institutionalism. An exploratory literature review. Cogent Business and Management, 7(1), 1-21. https://doi.org/10.1080/23311975.2020.1749217 
17. Hasanefendic, S., Birkholz, J. M., Horta, H., \& van der Sijde, P. (2017). Individuals in action: bringing about innovation in higher education. European Journal of Higher Education, 7(2), 101-119. https://doi.org/10.1080/21568235.2017.1296367

18. Herzog, P. (2011). Open and Closed Innovation: Different Culture for Different Strategies. Verlag: Gabler.

19. Hill, C. W. L., \& Hult, G. T. M. (2016). Global Business Today. New York: McGraw-Hill Education.

20. Ireland, R. D., Hoskisson, R. E., \& Hitt, M. A. (2011). The Management of Strategy: Concept and Cases. Mason: Cengage Learning.

21. Janssen, O. (2004). How fairness perceptions make innovative behaviour more or less stressful. Journal of Organizational Behaviour, 25(25), 201-215. https://doi.org/10.1002/job.238

22. Kandula. (2006). Performance Management: Strategies, Interventions, Drivers. New Delhi: Prentice Hall.

23. Kerlinger, F. N., \& Lee, H. B. (2000). Foundations of Behavioural Research. Forth Worth: Harcourt Collge Publishers.

24. Kinicki, A., \& Kreitner, R. (2008). Organizational Behaviour: Key Concepts, Skills \& Best Practice. New York: McGraw-Hill Company, Inc.

25. Kleysen, R. F., \& Street, C. T. (2001). Toward a multi-dimensional measure of individual innovative behaviour. Journal of Intelectual Capital, 2(3), 284-296. https://doi.org/https://doi.org/10.1108/EUM0000000005660

26. Koeslag-Kreunen, M. G. M., Van der Klink, M. R., Van den Bossche, P., \& Gijselaers, W. H. (2018). Leadership for team learning: the case of university teacher teams. Higher Education, 75(2), 191-207. https://doi.org/10.1007/s10734-017-0126-0

27. Lambriex-Schmitz, P., Van der Klink, M. R., Beausaert, S., Bijker, M., \& Segers, M. (2020). Towards successful innovations in education: Development and validation of a multi-dimensional Innovative Work Behaviour Instrument. Vocations and Learning, 13, 313-340. https://doi.org/10.1007/s12186-020-09242-4

28. Leal-Rodríguez, A. L., Eldridge, S., Ariza-Montes, J. A., \& Morales-Fernández, E. J. (2019). Understanding how organizational culture typology relates to organizational unlearning and innovation capabilities. Journal of the Knowledge Economy, 10(4), 1497-1514. https://doi.org/10.1007/s13132-015-0344-6

29. McMillan, J. H., \& Schumacher, S. (2006). Research in Education: Evidence-Based Inquiry. Boston: Pearson Education, Inc.

30. McShane, S. L., \& Glinow, M. A. von. (2015). Organizational Behaviour: Emering Knowledge, Global Reality. New York: McGraw-Hill/Irwin.

31. Naranjo-Valencia, J. C., Jiménez-Jiménez, D., \& Sanz-Valle, R. (2011). Innovation or imitation? the role of organizational culture. Management Decision, 49(1), 55-72. https://doi.org/https://doi.org/10.1108/00251741111094437

32. Nemeržitski, S., Loogma, K., Heinla, E., \& Eisenschmidt, E. (2013). Constructing model of teachers innovative behaviour in school environment. Teachers and Teaching: Theory and Practice, 19(4), 398-418. https://doi.org/10.1080/13540602.2013.770230

33. Niu, H. J. (2014). Is innovation behaviour congenital? Enhancing job satisfaction as a moderator. Personnel Review, 43(2), 288-302. https://doi.org/10.1108/PR-12-2012-0200

34. Pawirosumarto, S., Sarjana, P. K., \& Gunawan, R. (2017). The effect of work environment, leadership style, and organizational culture towards job satisfaction and its implication towards employee performance in Parador hotels and resorts, Indonesia. International Journal of Law and Management, 59(6), 1337-1358. https://doi.org/10.1108/IJLMA-10-2016-0085

35. QS World University Ranking. (2020). World University Ranking. Retrieved January 5, 2020, from https://www.topuniversities.com/university-rankings/world-university-rankings/2020

36. Schein, E. H. (2010). Organizational Culture and Leadership (4th ed.). San Fransisco: Jossey-Bass.

37. Scott, S. G., \& Bruce, R. A. (1994). Determinants of innovative behaviour: a path model of individual innovation in the workplace. Academy of Management Journal, 37(37), 580-607. https://doi.org/10.2307/256701

38. Shen, X., \& Tian, X. (2012). Academic Culture and Campus Culture of Universities. Higher Education Studies, 2(2), 61-65.

39. Sims, R. R. (2006). Human Resources Development: Today and Tomorrow. Connecticut: Information Age Publishing.

40. Spector, P. E. (1997). Job Satisfaction. California: SAGE Publications, Inc.

41. Stoffers, J., Neessen, P., \& Dorp, P. Van. (2015). Organizational culture and innovative work behaviour: A case study of a manufacturer of packaging machines. American Journal of Industrial and Business Management, 5, 198-207. https://doi.org/10.4236/ajibm.2015.54022 
42. Tien, L.-C., \& Chao, H. S. (2012). Effects of information culture and job satisfaction on the organizational innovation: a study of different leadership styles as a moderatoritle. Advances in Management \& Applied Economics, 2(3), 83-110. Retrieved from https://pdfs.semanticscholar.org/e00a/d9606f2db432e821e6472 a8a951dd700c448.pdf

43. Tiwari, S. K. (2009). Psychological Perspectives of Organizational Commitment. New Delhi: Concept Publishing Company.

44. Verloop, N., Driel, J. Van, \& Meijer, P. (2001). Teacher knowledge and the knowledge base of teaching. International Journal of Educational Research, 35(5), 441-461 Chapter. https://doi.org/doi:10.1016/s08830355(02)00003-4

45. Wicker, D. (2011). Job Satisfaction: Fact or Fiction. Bloomington: AuthorHouse.

46. Zavyalova, E., \& Kucherov, D. (2010). Relationship between organizational culture and job satisfaction in russian business enterprises. Human Resource Development International, 13(2), 225-235. https://doi.org/10.1080/13678861003703740. 